\title{
Effect of seed priming on growth and physiological traits of five Jordanian wheat (Triticum aestivum $\mathrm{L}$.) landraces under salt stress
}

\section{Samih M. Tamimi}

Dept. of Biological Sciences, Faculty of Science, The University of Jordan, Amman - Jordan

$\bowtie$ For any information: ask.author@journalbinet.com, Published online: 25 November 2016

\begin{abstract}
This study was conducted to evaluate the effects of salt stress and seed priming on germination performance, growth and physiology of five wheat (Triticum aestivum L.) landraces from Jordan namely; Ramtha, Ajloun, Madaba, Tafila and Karak. Results indicated that salinity decreased seed germination, relative water content, membranes stability index, shoot dry weight, leaf chlorophyll content and nitrate reductase activity. These effects were more pronounced in Ramtha, Ajloun and Madaba landraces as compared to Karak and Tafila. Significant increase in the accumulation of proline, total soluble sugars, soluble proteins and $\mathrm{H}_{2} \mathrm{O}_{2}$ was also observed in response to salinity, although variations existed among ladraces. Based on tolerance indices collected from parameters tested, the five landraces were clustered in two groups; Tafila and Karak landraces formed the first cluster while the second cluster consisted of Ajloun, Madaba and Ramtha landraces. The landraces of cluster 1 were classified, based on similarity and distance indices, as salt tolerant while those of cluster 2 were considered as salt sensitive Priming seeds with $50 \mathrm{mM} \mathrm{CaCl}{ }_{2}$ stimulated salt tolerance in all stressed wheat landraces via improving growth, stabilizing cell membranes, enhancing chlorophyll content, promoting the nitrate reductase activity and ROS scavenging activities in addition to up-regulating the accumulation of proline and soluble sugars. Results suggested that seed priming with $\mathrm{CaCl}_{2}$ can be utilized for enhancing the salt tolerance potential of wheat and could contribute to promoting its cultivation in salt affected soils.
\end{abstract}

Key Words: Triticum aestivum, Stress, Salinity, Priming, Growth and Germination

Cite article: Tamimi, S. M. (2016). Effect of seed priming on growth and physiological traits of five Jordanian wheat (Triticum aestivum L.) landraces under salt stress. Journal of Bioscience and Agriculture Research, 11(01), 906-922.

Article distributed under terms of a Creative Common Attribution 4.0 International License.

\section{Introduction}

Salinity is one of the most serious environmental stress factors affecting wheat (Triticum aestivum L.) cultivation in arid and semi-arid regions including Jordan. Salt stress affects almost all stages of wheat growth and development however, seed germination and seedling establishment are the most sensitive to salinity. (Kochak-Zadeh et al., 2013). The detrimental effects of salt on wheat and other plants are a consequence of both water deficit resulting in osmotic stress and the effects of excess salt 
ions on critical biochemical processes (Wyn-Jones, 1981). Numerous physiological and biochemical changes occur in response to salt stress including reduced absorption of water (Park et al., 2016), ionic imbalance (Jaleel et al., 2008), reduction of enzyme activities (Ashraf et al., 2004), disruption of nitrogen metabolism (Lorenzo et al., 2001), reduction of chlorophyll content (Dubey, 2005) and imbalance in the cellular redox homeostasis which results in an increase in the rate of production of reactive oxygen species (ROS) such as superoxide radical $\left(\mathrm{O}_{2}^{-}\right)$, hydrogen peroxide $\left(\mathrm{H}_{2} \mathrm{O}_{2}\right)$ and hydroxyl radical $(\mathrm{OH})$ (Apel and Hirt, 2004). These and other changes are responsible for the deterioration of many vital processes in plants such as inhibition or delayed germination, high rate of seedling morality, stunted growth and reduced yield (Almansouri et al., 2001).

Wheat is a moderately salt-tolerant crop and its yield is substantially reduced as the soil salinity level rises to $100 \mathrm{mM} \mathrm{NaCl}$ (Munns et al., 2006). Thus the use of wheat verities with increased tolerance to salinity is necessary to improve its productivity under saline conditions. Plants resort to many adaptive strategies in response to salinity. These include osmotic adjustment through the accumulation of compatible organic solutes such as proline and soluble sugars (Yancy, 2005), changes in physiological and biochemical traits such as prevention of fatal relative water content, high cell membrane stability, increased photosynthetic activity, modulation of different enzymes characters and an increase in plant antioxidant activity that detoxify ROS to counteract oxygen radicals (Ashraf and Harris, 2004). Therefore, examining plant traits with sound and positive association with salinity tolerance are necessary for the identification of salinity tolerant cultivars.

Local landraces are important genetic resources for improvement of crops in saline areas, since they have accumulated adaptation to harsh environment over long time. In fact, local landraces are considered the backbone of agricultural production in many developing countries due to their ability to produce some yield even in difficult conditions (Brush, 1999). To improve the capacities of plants to salinity tolerance, pre-sowing seed treatments (priming) with different solutions such as inorganic salts, sugars and growth regulators have been employed and demonstrated to have positive effects on seed germination and subsequent growth of wheat and other crop plants under saline conditions (Ashraf and Ruaf, 2001; Jamal et al., 2011).

Keeping in view the negative effects of salt stress on wheat cultivation, the present study was undertaken to evaluate five Jordanian landraces of wheat at germination and seedling stage for salt tolerance and to determine their behavior in response to seed priming treatment. Seed priming strategy was investigated based on the potential of priming to adjust selected physiological and biochemical parameters that might improve salt tolerance.

\section{Materials and Methods}

Seed material and priming treatments: Seeds of 5 wheat (Triticum aestivum L.) landraces from different locations in Jordan namely; Ramtha, Ajloun, Madaba, Tafila and Karak were selected for this study. Their selection was based on the different altitude of their traditional cultivation and potential exposure to harsh environmental conditions. The seeds were surface sterilized with $5 \%$ sodium hypochlorite solution for $10 \mathrm{~min}$ and then thoroughly washed with sterile distilled water. Subsequently the seeds were primed by soaking with either sterile water (hydropriming) or sterile solution of $50 \mathrm{mM}$ of $\mathrm{NaCl}$ or $\mathrm{CaCl}_{2}$ (osmopriming) for $12 \mathrm{~h}$ at room temperature. After priming, seeds were washed with distilled water and were left in air between two filter papers to re-dry to their original moisture level.

Seed germination and seedling growth: Germination potential of primed and un-primed wheat seeds was estimated in accordance with the International Rules for Seed Testing (ISTA, 1985). Four replicates of twenty five seeds per landrace form each priming treatment and un-primed (UP) control were germinated in $90 \mathrm{~mm}$ diameter petri dishes on two layers of Whatman no. 2 filter paper moistened with $10 \mathrm{ml}$ of the appropriate salt test solutions $(0,50,100,150,200$ and $250 \mathrm{mM} \mathrm{NaCl})$ every 2 days. The petri dishes were placed in an incubator at $28^{\circ} \mathrm{C}$ under dark conditions in a randomized block design. Seed germination percentage was calculated after 8-d from the start of the experiment. Seeds were considered to be germinated when they exhibited a radicle extension longer than $2 \mathrm{~mm}$ (Bewley and Black, 1994). 
Seed germination recovery test: Seed recovery from the inhibitory effect of salinity was determined according to the method of Almansouri et al. (2001) with modifications. Twenty five seeds from each wheat landrace were imbibed for $12 \mathrm{~h}$ in saline solutions of $500 \mathrm{mM} \mathrm{NaCl}$. Imbibed seeds were germinated in $90 \mathrm{~mm}$ diameter petri dishes on two layers of Whatman no.2 filter paper moistened with $10 \mathrm{ml} \mathrm{NaCl}$ solution of the same concentration used for seed imbibition. Petri dishes were incubated in the dark at $28{ }^{\circ} \mathrm{C}$. After 5 days, un-germinated seeds were rinsed with distilled water and transferred to fresh petri dishes with filter paper moistened with $5 \mathrm{ml}$ distilled water daily. Seed recovery was quantified as the germination percentages of rinsed seeds after 5 days.

Seedling experiments: Fifteen UPseeds (used as control) and $\mathrm{CaCl}_{2}$ primed seeds from each wheat landrace were sown at a depth of $2 \mathrm{~cm}$, in plastic pots $(20 \mathrm{~cm}$ diameter and $25 \mathrm{~cm}$ height $)$ filled with peat and topsoil $(1 / 3: 2 / 3)$. Pots were kept in the greenhouse under normal light $\left(\right.$ at $22 / 11^{\circ} \mathrm{C}$ ) and irrigated with tap water till 3 leaf stage. Salt stress was then imposed by irrigating UP and primed seedlings every 3 days with $150 \mathrm{ml}$ of $250 \mathrm{mM} \mathrm{NaCl}$. Non-stressed plants were irrigated with tap water. Pots were arranged in a completely randomized block design with 4-5 replications per treatment. Two weeks after the imposition of stress, the shoots of five randomly selected plants from each treatment were dried in an oven at $70^{\circ} \mathrm{C}$ for $48 \mathrm{~h}$ and weighed for recording shoot dry weight. The remaining plants in pots were evaluated for metabolic and physiological parameters.

Leaf relative water content (RWC): Leaf RWC was determined following the method described by Muranaka et al., (2002). Leaf samles (0.5 g) were randomly selected from each treatmentcut into smaller pieces and weighed to determine initial weight (Wi).0 The leaf samples were then floated in distilled water for $6 \mathrm{~h}$ and weighed thereafter to determine turgid weight (Wf). The samples were oven-dried at $80^{\circ} \mathrm{C}$ for 3 days and the dry weight was obtained (Wd). The RWC was determined using the following formula: $\mathrm{RWC}=(\mathrm{Wi}-\mathrm{Wd})(\mathrm{Wf}-\mathrm{Wd})^{-1} 100$.

Membrane stability index (MSI): Leaf MSI was determined according to Sairam et al. (1994). Leaf discs $(100 \mathrm{mg}$ ) from each treatment were thoroughly washed in running tap water followed by washing with distilled water. Thereafter the discs were heated in $10 \mathrm{ml}$ distilled water at $40^{\circ} \mathrm{C}$ for $30 \mathrm{~min}$ and its conductivity (C1) was recorded using conductivity meter. Subsequently the same samples were placed in a boiling water bath $\left(100^{\circ} \mathrm{C}\right)$ for $10 \mathrm{~min}$ and their conductivity was also recorded (C2). MSI was then calculated as: MSI= [1-(C1/C2)] x100.

Chlorophyll Content: For chlorophyll extraction, $0.5 \mathrm{~g}$ fresh leaf material randomly selected from each treatment was ground in $80 \%$ acetone and the absorbance was read spectrophotometrically at 663 and $645 \mathrm{~nm}$. Total chlorophyll content (mg.g-1 fresh weight) was estimated by the method of Arnon (1949).

Proline content: Proline content was estimated using the method described by Bates et al. (1973). Fresh leaves $(0.5 \mathrm{~g} /$ treatment $)$ were extracted in $5 \mathrm{ml}$ of $3 \%$ sulphosalicylic acid, and the homogenates were centrifuged at 12,000 rpm for $10 \mathrm{~min}$. A $2 \mathrm{ml}$ of the supernatant were mixed with $4 \mathrm{ml}$ of $2.5 \%$ acid ninhydrin and $2 \mathrm{ml}$ glacial acetic acid and the mixture was boiled in a water bath at $100{ }^{\circ} \mathrm{C}$ for $1 \mathrm{~h}$. The chromophore formed was extracted with $4 \mathrm{ml}$ of toluene and mixed vigorously by vortexing. Absorbance of the resulting organic layer was measured at $520 \mathrm{~nm}$ and the concentration of proline was estimated by referring to proline standard curve.

Soluble Sugar Content: Total soluble sugars were extracted by homogenizing $25 \mathrm{mg}$ dried leaf material in $5 \mathrm{ml} 80 \%$ ethanol boiled in a water bath at $70^{\circ} \mathrm{C}$ for $30 \mathrm{~min}$ and centrifuged at $12,000 \mathrm{rpm}$ for $10 \mathrm{~min}$. The supernatant was used for the estimation of total soluble sugars by the anthrone method using glucose as the standard (Yemm and Willis, 1954).

Total Soluble Proteins: Leaf total soluble protein was determined according to Bradford (1976) using Bovine serum albumin as a standard. A $0.5 \mathrm{~g}$ fresh leaf tissue/treatment were ground in $2 \mathrm{ml}$ of phosphate buffer $\mathrm{pH} 7.2$ and the he homogenate was centrifuged at 10,000 rpm for $15 \mathrm{~min} .10 \mu \mathrm{l}$ of supernatant and $25 \mu \mathrm{l}$ distilled water were added to $3 \mathrm{ml}$ Bradford reagent. Absorbance of the resulting mixture was recorded at $595 \mathrm{~nm}$ and the total soluble protein content was quantified from the standard curve. 
Estimation of hydrogen peroxide: The content of $\mathrm{H}_{2} \mathrm{O}_{2}$ in leaves was determined according to Velikova et al. (2000). Fresh leaves $(0.1 \mathrm{~g} /$ treatment) were homogenized in $5 \mathrm{ml}$ of $0.1 \%$ Trichloroacetic acid (TCA) and centrifuged at 12,000 rpm for 15 minutes. A $0.5 \mathrm{ml}$ of the supernatant was then mixed with $0.5 \mathrm{ml}$ of $10 \mathrm{mM}$ potassium phosphate buffer ( $\mathrm{pH} 7$ ) and $1 \mathrm{ml}$ of $1 \mathrm{M}$ KI. The absorbance of the resulting mixture was taken at $390 \mathrm{~nm}$ and $\mathrm{H}_{2} \mathrm{O}_{2}$ content was determined from a standard curve.

Nitrate Reductase (NR) Activity: NR activity was determined by the method of Silveira et al. (1998). Leaf discs $(0.5 \mathrm{gm}$ fresh mass) were infiltrated twice for two minutes with $5 \mathrm{ml}$ of reaction mixture containing $4 \mathrm{ml}$ of $0.2 \mathrm{M}$ phosphate buffer (pH7.5), $0.5 \mathrm{ml}$ of $0.1 \mathrm{M} \mathrm{KNO}_{3}$ and $0.5 \mathrm{ml}$ of $1 \%$ Isopropanol. The reaction mixture was incubated at $30^{\circ} \mathrm{C}$ for $30 \mathrm{~min}$ in the dark. NR activity was estimated from the amount of $\mathrm{NO}_{2}$ - formed during the incubation period and released from the leaf discs to the medium after boiling for 5 minutes. Aliquots $(1 \mathrm{ml})$ of incubation mixture was taken out and mixed with $2 \mathrm{ml}$ of (1:1) $1 \%$ sulfanilamide in $2.4 \mathrm{~mol} / \mathrm{l} \mathrm{HCl} ; 0.02 \% \mathrm{~N}$-1-naphtyl-ethylenediamine and the absorbance was taken at $540 \mathrm{~nm}$. NR activity in terms of release of $\mu$ mole $\mathrm{NO}_{2}{ }^{-} \mathrm{h}^{-1} \mathrm{~g}^{-1}$ fresh weight was calculated by the help of standard curve, prepared by $\mathrm{NaNO}_{2}$.

Landrace clustering: Discriminating traits between the tested landraces for the response to $250 \mathrm{mM}$ $\mathrm{NaCl}$ were identified through cluster analysis of the means of salt tolerance indices of all tested parameters using the Past 3 software. Tolerance indices of traits were calculated using the formula; Tolerance index (TOL) $=$ Yp - Ys (Rosielle and Hamblin, 1981) where Ys and Yp are the response of landraces evaluated under saline (stress) and non-saline (non-stress) conditions.

Statistical analysis: The data presented are means from 4-5 replicates per treatment \pm SE. Means were compared between treatments (when necessary) by Duncan Multiple Range Test (DMRT) at the 0.05 confidence level (Steel and Torrie, 1997).

\section{Results and Discussion}

Results presented in Figure 01 showed that the mean percent germination in the wheat landraces tested gradually declined as the concentrations of salinity increased from $50 \mathrm{mM}$ to $250 \mathrm{mM} \mathrm{NaCl}$, although variations existed among landraces (Figure 01). The highest percentage of seed germination $(\geq 90 \%$ ) was observed in control treatments (no stress) and the maximum decline in germination counts was recorded at $250 \mathrm{mM} \mathrm{NaCl}$ solution. At this $\mathrm{NaCl}$ level, seeds of Madaba, Ajloun and Ramtha landraces showed the lowest germination percentage (10\%-15\%) while Karak and Tafila landraces, were more tolerant to salinity and exhibited higher germination percentage (40\%-45\%). Seed priming significantly enhanced germination percentage under all salinity levels irrespective of variety. Priming seeds with $50 \mathrm{mM} \mathrm{CaCl} 2$ had the maximum beneficial impact on germination. This treatment resulted in a 3-4fold increase in percent germination over their UP controls in Ramtha, Madaba and Ajloun landraces while it doubled seed germination of Tafila and Karak landraces. Seeds primed with 50mM $\mathrm{NaCl}$ and hydroprimed seeds, on the other hand, showed lower germination potential under the imposed salinity stress. For this reason, only $\mathrm{CaCl}_{2}$ priming treatment was chosen to find out if priming improves the biochemical and physiological activities of wheat seedlings at $250 \mathrm{mM} \mathrm{NaCl}$ salinity.

Results of seed germination recovery in distilled water applied to ungerminated seeds after pretreatment with $500 \mathrm{mM} \mathrm{NaCl}$ showed that seeds of Karak and Tafila landraces recovered by $90 \%$ while the percentages recovery for Ajloun, Ramtha and Madaba landraces were 78\%, 62\% and 48\%, respectively (Figure 02). These results suggested that seeds of Tafila and Karak landraces were the least damaged by salinity stress.

Results of Figure 03 indicated that salinity significantly $(\mathrm{P}<0.05)$ decreased shoot dry weight of plants derived from UP seeds of all landraces. The highest reduction of shoot dry weight relative to unstressed control was 40\% for Ramtha landrace whereas Madaba, Ajloun, Karak and Tafila landraces showed lower reduction in shoot dry weights averaging $22 \%, 25 \%, 20 \%$ and $15 \%$, respectively, relative to their unstressed controls. $\mathrm{CaCl}_{2}$ priming improved shoot dry weight in all landraces by 10 $15 \%$ and proved to be useful in decreasing the negative effects of salinity on the growth performance of wheat. 
Leaf relative water content (RWC) of UP plants was significantly reduced by salinity compared to unstressed control (Figure 04). The highest reduction were recorded for Ramtha, Ajloun and Madaba landraces (25\%-27\%). The reduction of leaf RWC observed in Karak and Tafila landraces was significantly lower $(12 \%-15 \%$ relative to unstressed control) indicating that these landraces were more adapted to salinity.

$\mathrm{CaCl}_{2}$ priming enhanced leaf RWC in stressed plants particularly in Ramtha, Ajloun and Madab landraces. However, the priming treatment had insignificant influence on leaf RWC of Karak and Madaba landraces when compared with UP plants.

Considerable reduction in shoot membrane stability index (MSI) of plants grown under salinity stress compared to unstressed control was evident in all the landraces tested (Figure 05). The lowest reduction of MSI (18\%) was observed in plants of Tafila landrace. The remaining landraces showed higher reduction of MSI; 24\% for Karak, 30\% for Madaba and Ajloun and 36\% for Ramtha. The MSI of plants from primed seeds was significantly improved under salinity compared to UP control. Plants of Madaba, Ramtha and Ajloun landraces showed the highest increase in MSI response to priming (18\%$23 \%$ relative to UP controls) compared to plants of Karak and Tafila which showed $10 \%$ to $12 \%$ improvement of MSI.

Salt stress significantly reduced total leaf chlorophyll content and this response varied among landraces (Figure 06). The least affected plants were those of Tafila and Karak landraces. In these plants the reduction in total chlorophyll content averaged $22 \%$ and $26 \%$, respectively, compared to un-stressed plants. While plants of Madaba, Ajloun and Ramtha landraces showed higher decline in leaf chlorophyll averaging 35\%, 36\% and $40 \%$ respectively. $\mathrm{CaCl}_{2}$ priming treatment improved chlorophyll content of all wheat plants under saline conditions by $8 \%$ to $18 \%$ compared to UP plants. although, the highest improvement was observed in plants of Madaba and Ajloun landraces.

Leaf proline content of all landraces was significantly influenced by salinity (Figure 07). Under unstressed conditions, leaf proline content was relatively low and the highest content was seen in plants of Madaba landrace. A sharp increase in leaf proline content occurred when plants were exposed to salinity stress. The largest increase (approximately 4 folds over non stressed control) was recorded in plants of Tafila landrace while lower levels of proline accumulation was oberved in leaves of Madaba, Karak, Ajloun and Ramtha landraces (2-3 folds higher than their respective unstressed control). Priming with $\mathrm{CaCl}_{2}$ increased leaf proline content in stressed plants of Madaba, Ajloun, Ramtha, Tafila and Karak landraces by 8\%,14\%,16.5\%,18\% and 22\%, respectively, over their UP controls.

Application of salinity stress increased shoot soluble sugars compared to unstressed control (Figure 08). In plants of Karak and Madaba landraces, shoot soluble sugars increased by approximately $10 \%$ relative to their respective controls while the increase was most prominent (37\% over control) in plants of Tafila landrace and the lowest (4\%) in plants of Ajloun landrace. Seed priming with $\mathrm{CaCl}_{2}$ resulted in additional increase in total sugars only in plants of Karak and Ajloun landraces but had insignificant influence on shoot soluble sugar content of Ramtha, Madaba and Tafila landraces.

The influence of salinity on leaf NR activity of wheat plants is presented in Figure 09. Compared to control plants, salinity stress reduced the NR activity in leaves of all wheat landraces used in this study by $22 \%-26 \%$. Priming with $\mathrm{CaCl}_{2}$ stimulated $\mathrm{NR}$ activity under stress and the degree of stimulation differed among landraces. The largest enhancement of NR activity was observed in Karak and Tafila landraces $(16.5 \%$ and $18 \%$ respectively over UP control), whereas the activity was stimulated by $9 \%, 12 \%, 13.5 \%$, in Ajloun, Ramtha and Madaba landraces, respectively, over UP controls.

Results of Figure 10 demonstrated a landrace dependent increase in the content of soluble protein in stressed plants compared to controls. This increase was the highest (15\%-20\% relative to control) in Ramtha, Tafila and Karak landraces, however no significant change in protein content was observed in stressed plants of Ajloun, and Madaba landraces when compared with their respective controls. In all 
landraces, however, priming with $\mathrm{CaCl}_{2}$ caused little or no increase in the total soluble protein content compared with UP plants.

Hydrogen peroxide content of the leaves increased significantly with salinity treatment (Figure 11). The highest increase in $\mathrm{H}_{2} \mathrm{O}_{2}$ content was observed in plants of Madaba landrace (42\% over control). The recorded increase in $\mathrm{H}_{2} \mathrm{O}_{2}$ levels for Ramtha, Ajloun, Tafila and Kara landraces were lower and averaged $34 \%, 22 \%, 16 \%$ and $20 \%$, respectively, over their unstressed control. $\mathrm{CaCl}_{2}$ priming treatment reduced leaf $\mathrm{H}_{2} \mathrm{O}_{2}$ level in stressed plants of all landraces. The maximum reduction (25\%) was observed in plants of Ramtha and Tafila landraces while lower reduction (10\%-15\% relative to UP controls) was seen in plants of Madaba, Ajloun and Karak landraces.

Cluster diagram based on tolerance indices of data collected from all traits studied grouped the tested landraces into two clusters (Figure 12). Tafila and Karak landraces formed the first cluster while the second cluster consisted of Ajloun, Madaba and Ramtha landraces. Based on similarity and distance indices, the landraces of cluster 1 were classified as salt tolerant while those of cluster2 were considered as salt sensitive, although Ramtha landrace was the most sensitive to salinity among the landraces of this cluster.

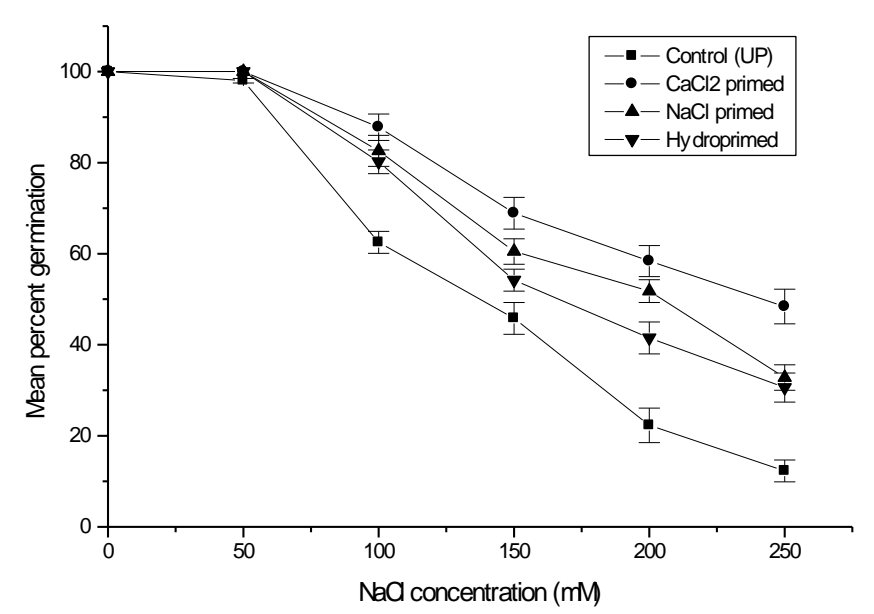

(A)

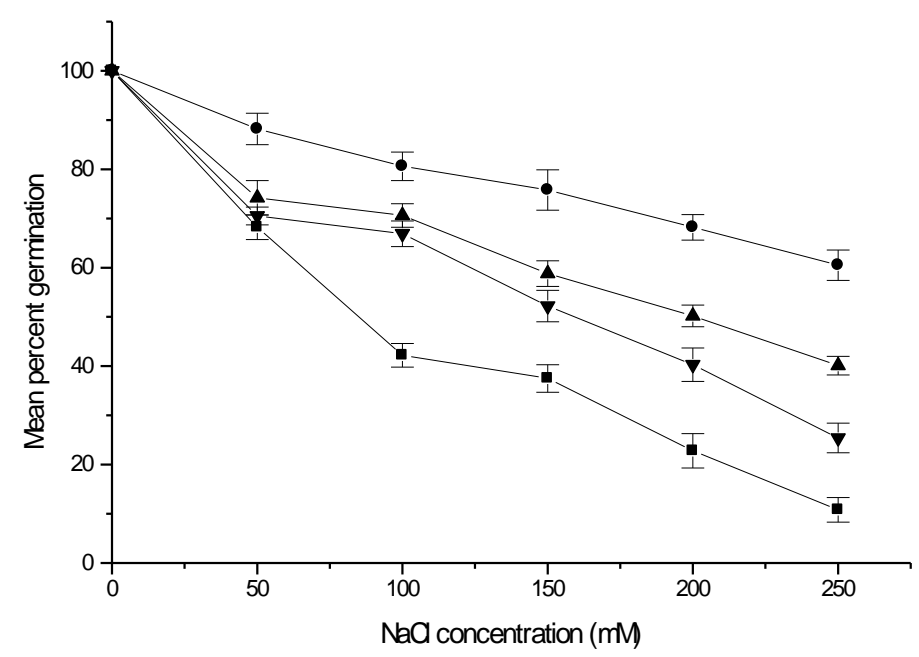

(C)

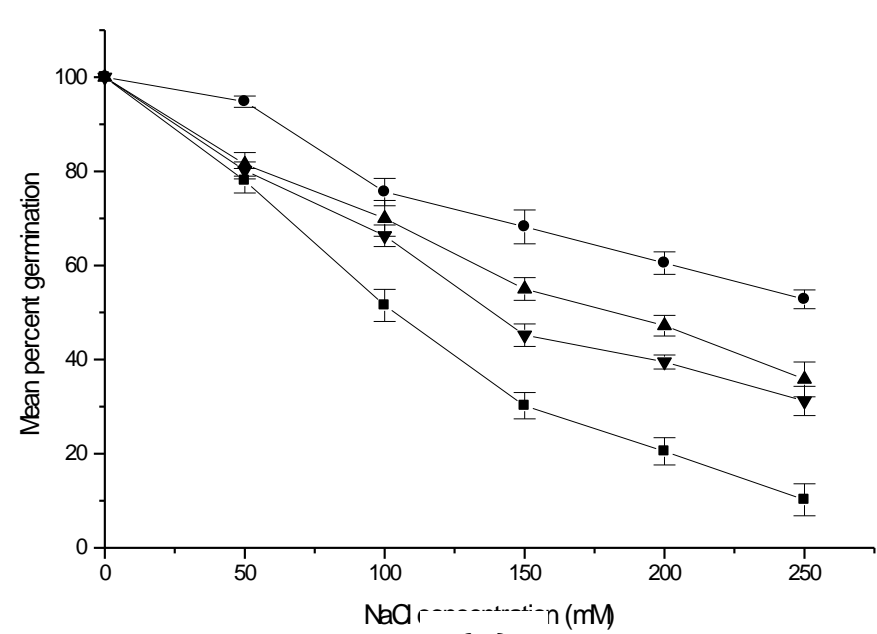

(B)

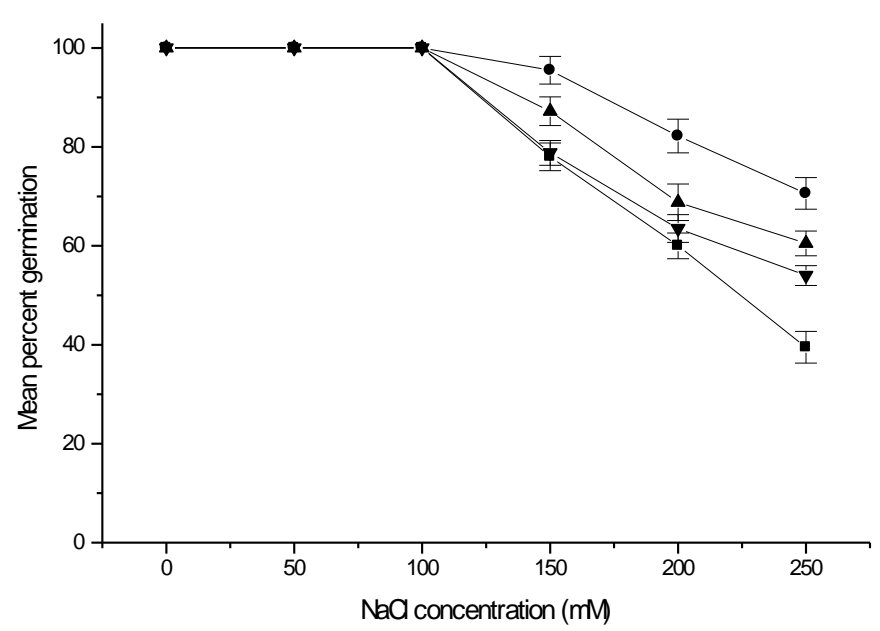

(D) 


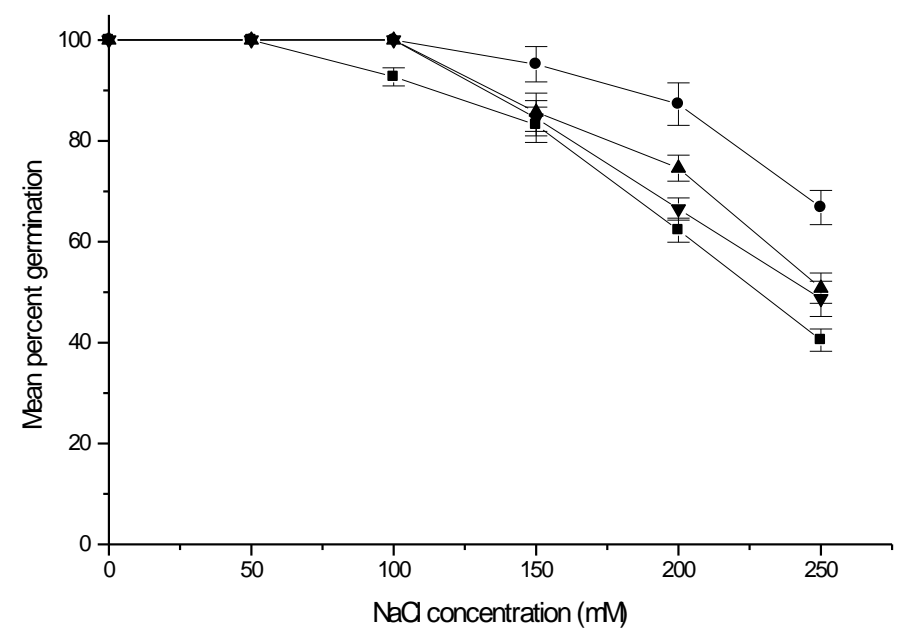

(E)

Figure 01. Effect of seed priming on the germination of wheat landraces; Ramtha (A), Ajloun (B), Madaba (C), Karak (D) and Tafila (E) under different $\mathrm{NaCl}$ salinity levels. Data represent the mean percent germination values $\pm S E$.

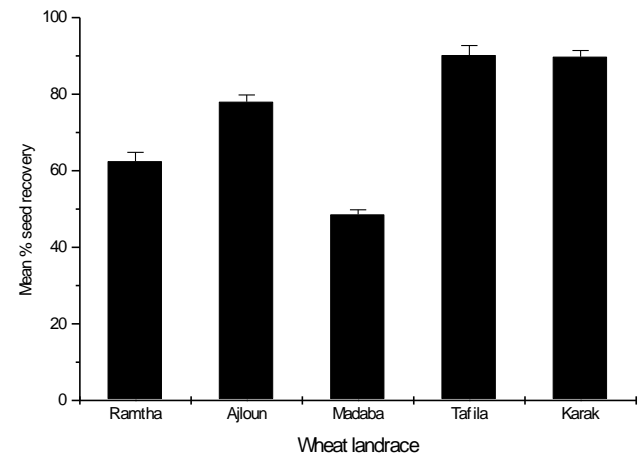

Figure 02. Recovery of germination (mean \pm SE) of wheat seeds upon transfer to distilled water after exposure to $500 \mathrm{mM} \mathrm{NaCl}$ pretreatment.

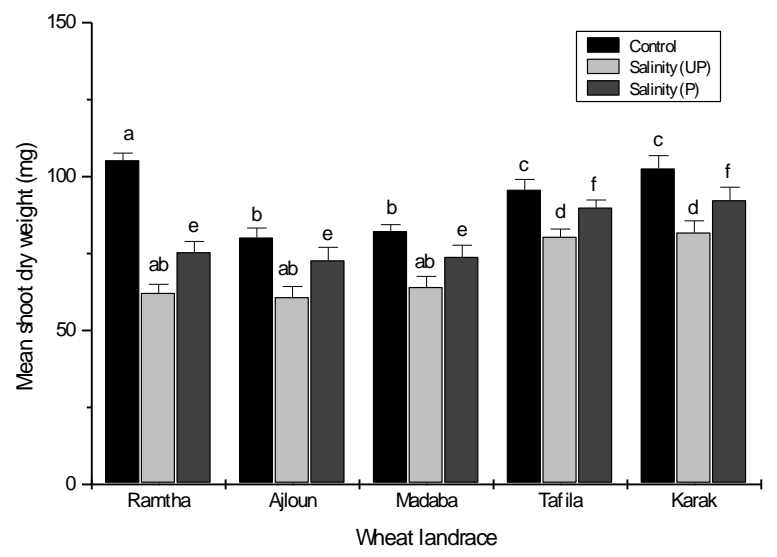

Figure 03. Effect of $\mathrm{CaCl}_{2}$ priming on shoot dry weight of wheat landraces under $250 \mathrm{mM} \mathrm{NaCl}$ salinity stress. Means with the same letters are not significantly different according to the Duncan's multiple range test $(\mathrm{P}<0.05)$. 


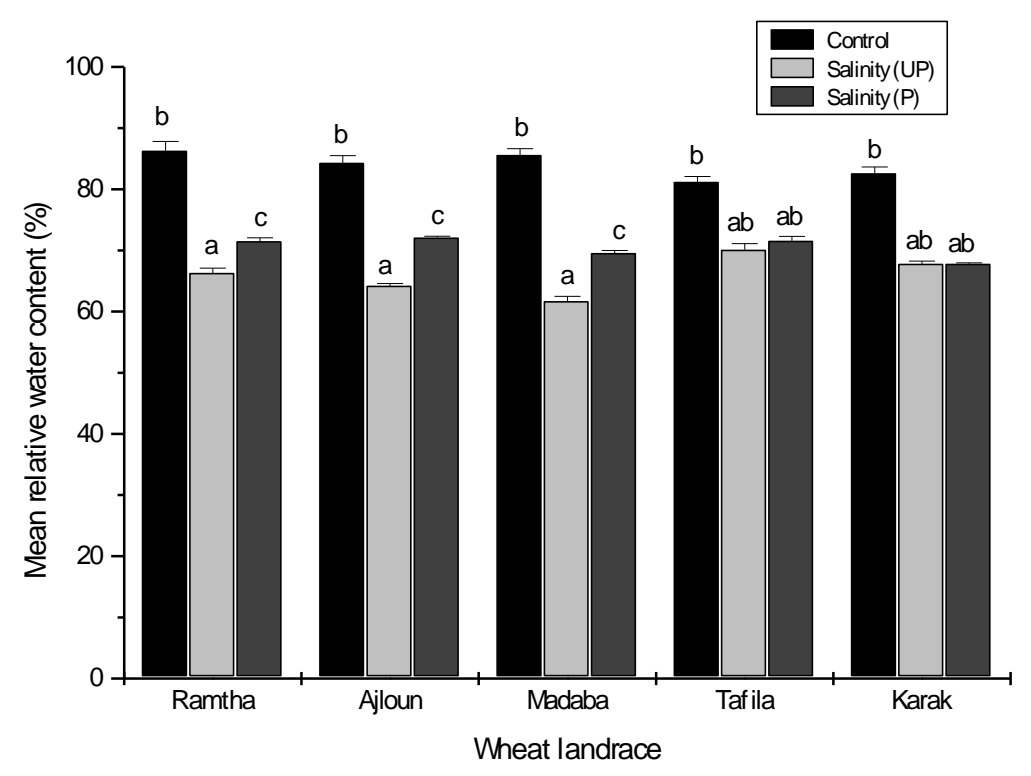

Figure 04. Effect of $\mathrm{CaCl}_{2}$ priming on relative water content (RWC) of wheat landraces. Means with the same letters are not significantly different according to the Duncan's multiple range test $(\mathrm{P}<0.05)$.

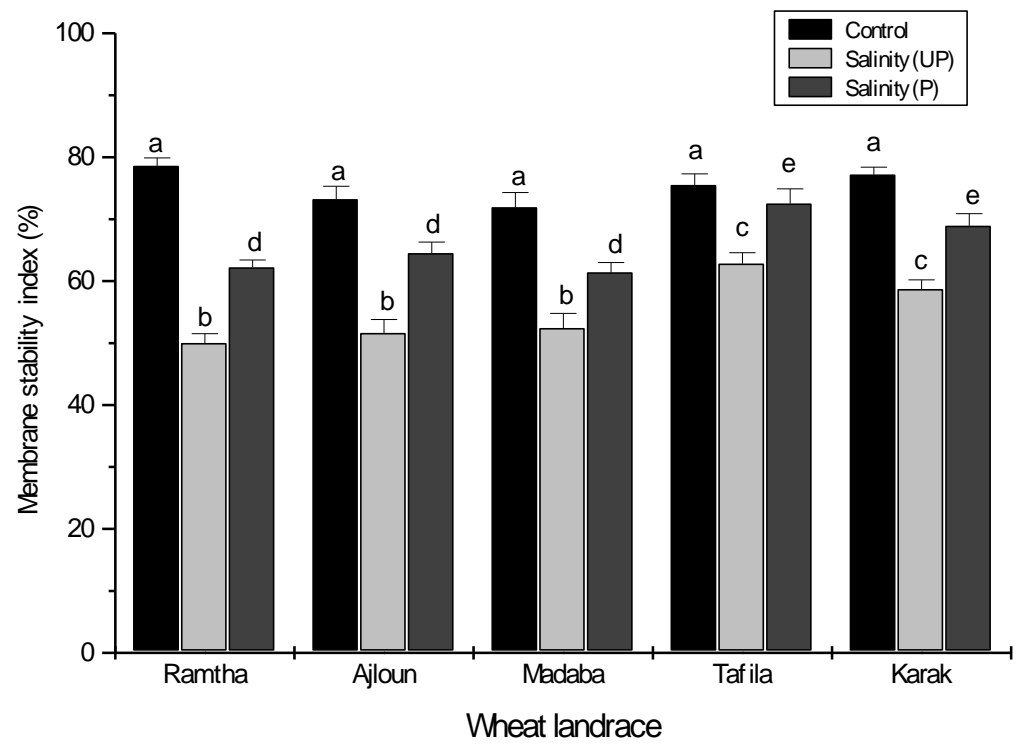

Figure 05. Effect of $\mathrm{CaCl}_{2}$ priming on membrane stability index of wheat landraces exposed to $250 \mathrm{mM} \mathrm{NaCl}$ salinity treatment. . Means with the same letters are not significantly different according to the Duncan's multiple range test $(P<0.05)$. 


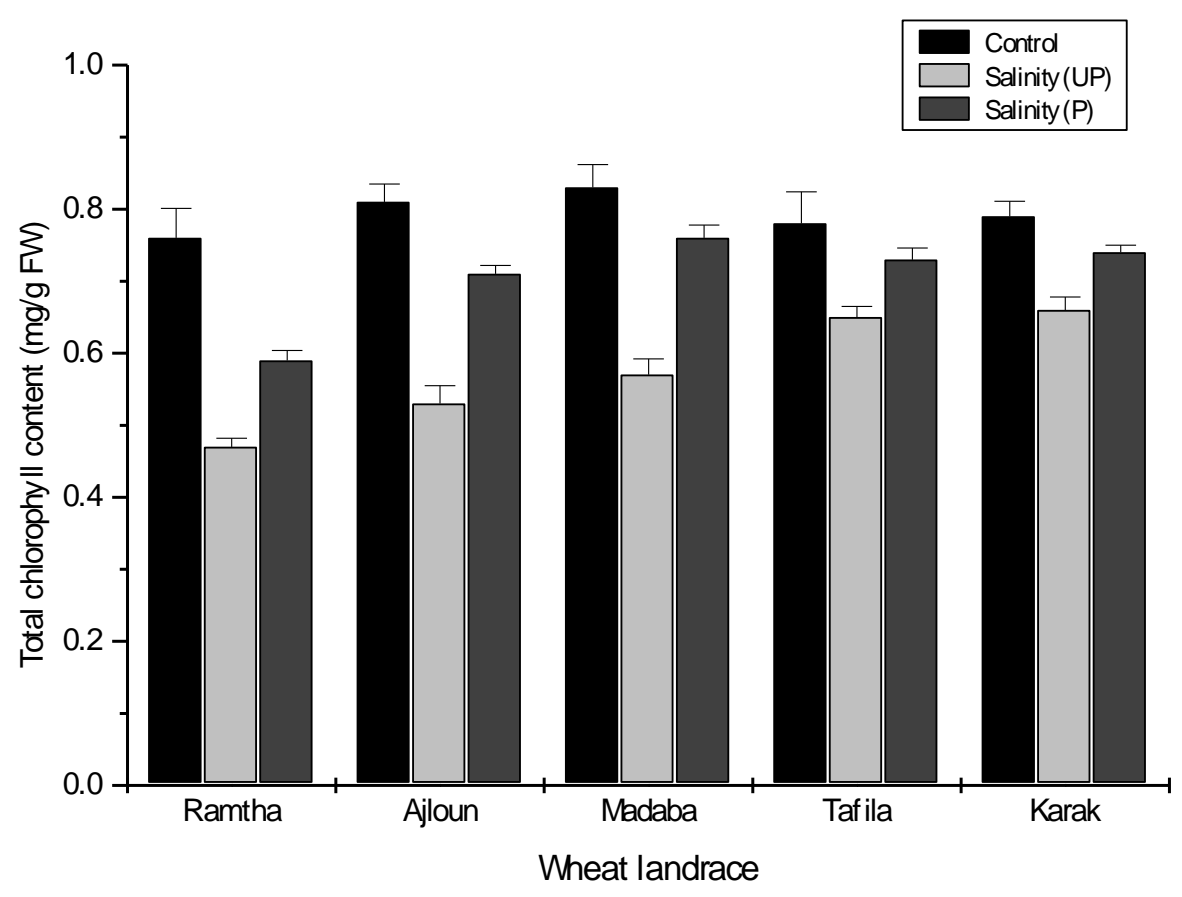

Figure 06. Effect of $\mathrm{CaCl}_{2}$ priming on total leaf chlorophyll content in wheat landraces under $250 \mathrm{mM}$ NaCl salinity stress Data represent means from 5 replicates \pm SE.

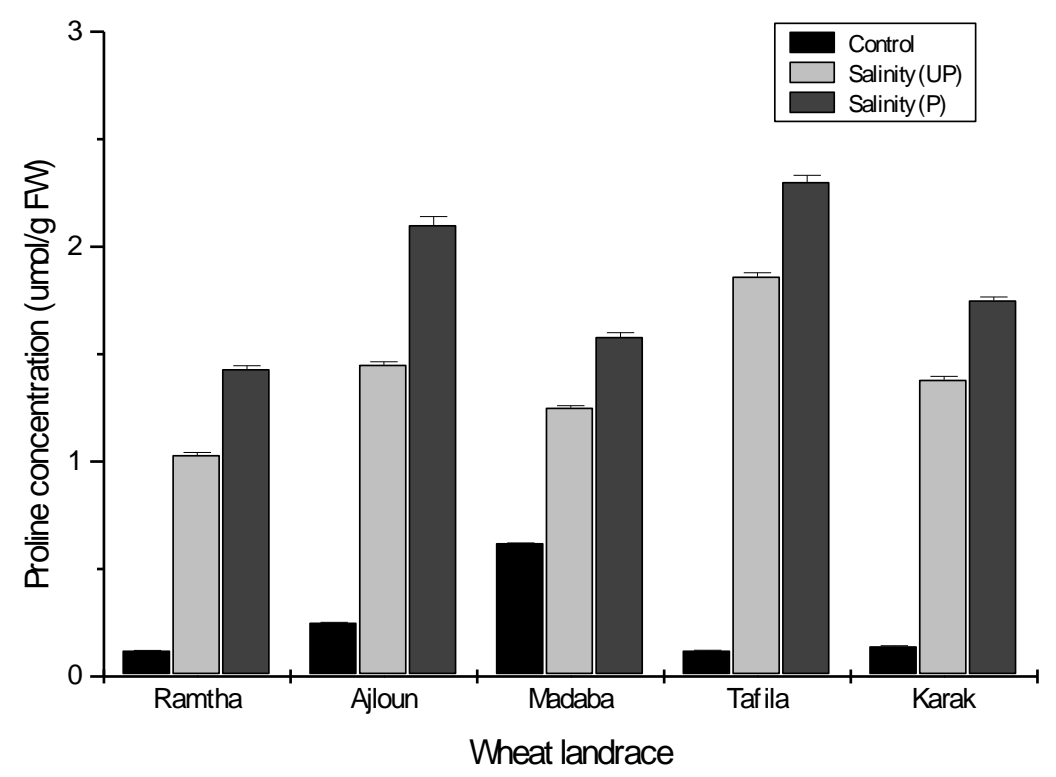

Figure 07. Effect of seed priming with $\mathrm{CaCl}_{2}$ on proline content of wheat landraces subjected to $250 \mathrm{mM}$ NaCl salinity stress. Data represent means from 5 replicates \pm SE. 


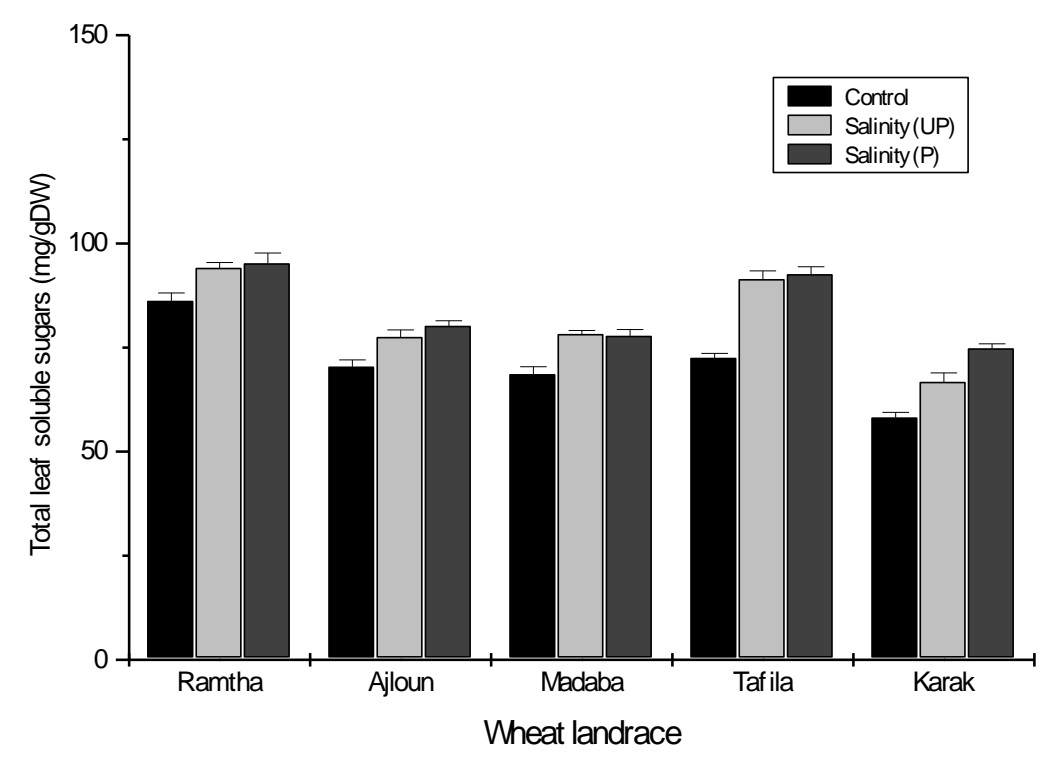

Figure 08. Effect of $\mathrm{CaCl}_{2}$ priming on the content of total soluble sugars in wheat landraces exposed to $250 \mathrm{mM} \mathrm{NaCl}$ salinity. Data represent means from 4 replicates $\pm \mathrm{SE}$.

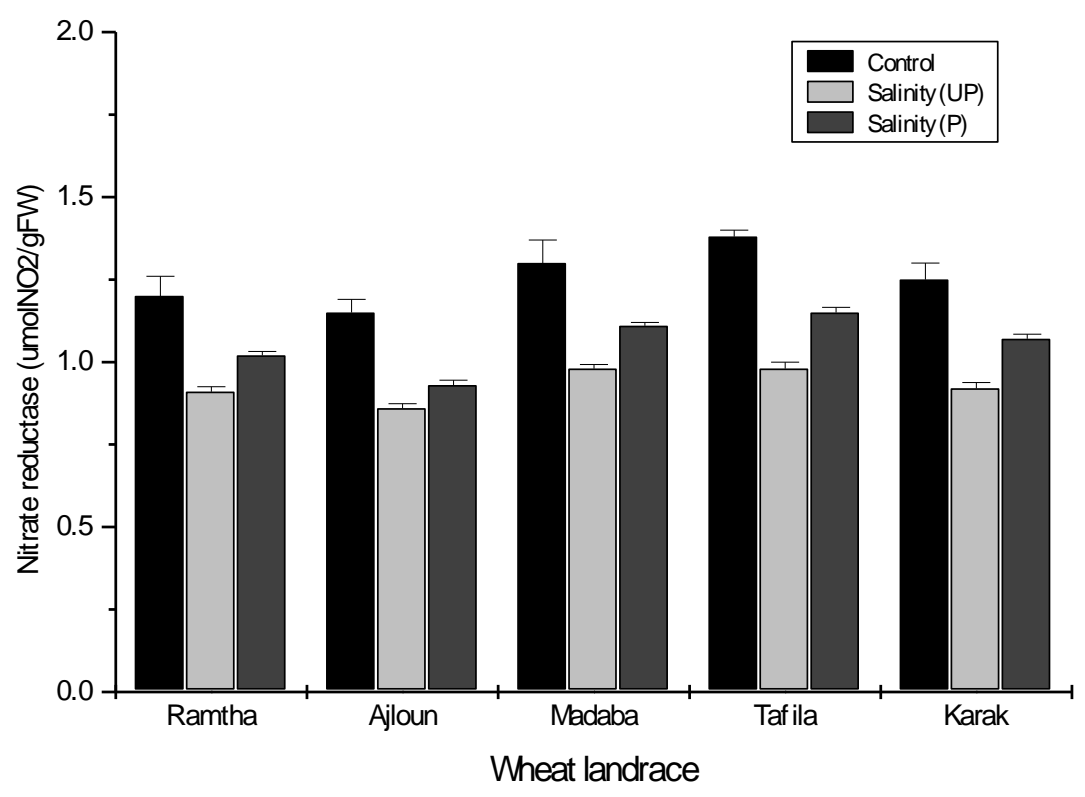

Figure 09. Effect of $\mathrm{CaCl}_{2}$ priming on the activity of Nitrate Reductase (NR) in leaves of wheat landraces grown under $250 \mathrm{mM} \mathrm{NaCl}$ salinity. Data represent means from 4 replicates $\pm \mathrm{SE}$. 


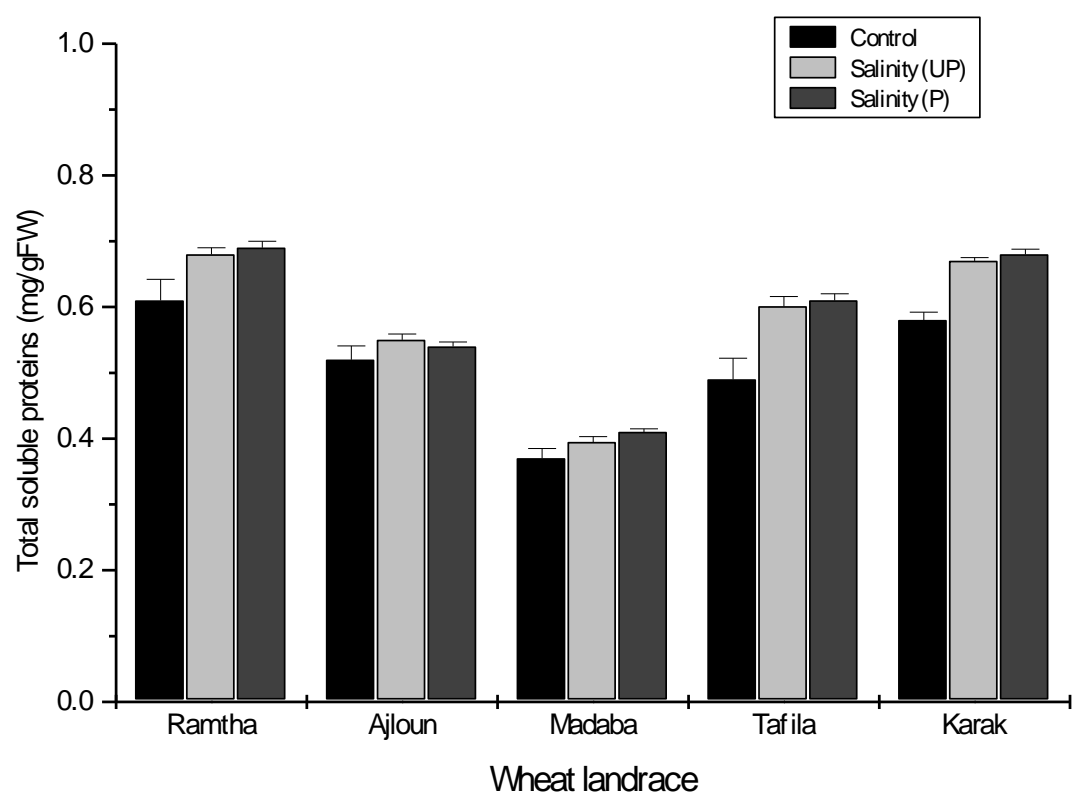

Figure 10. Effect of $\mathrm{CaCl}_{2}$ priming on leaf total soluble proteins of wheat landraces grown under $250 \mathrm{mM} \mathrm{NaCl}$ salinity. Data represent means from 4 replicates $\pm S E$.

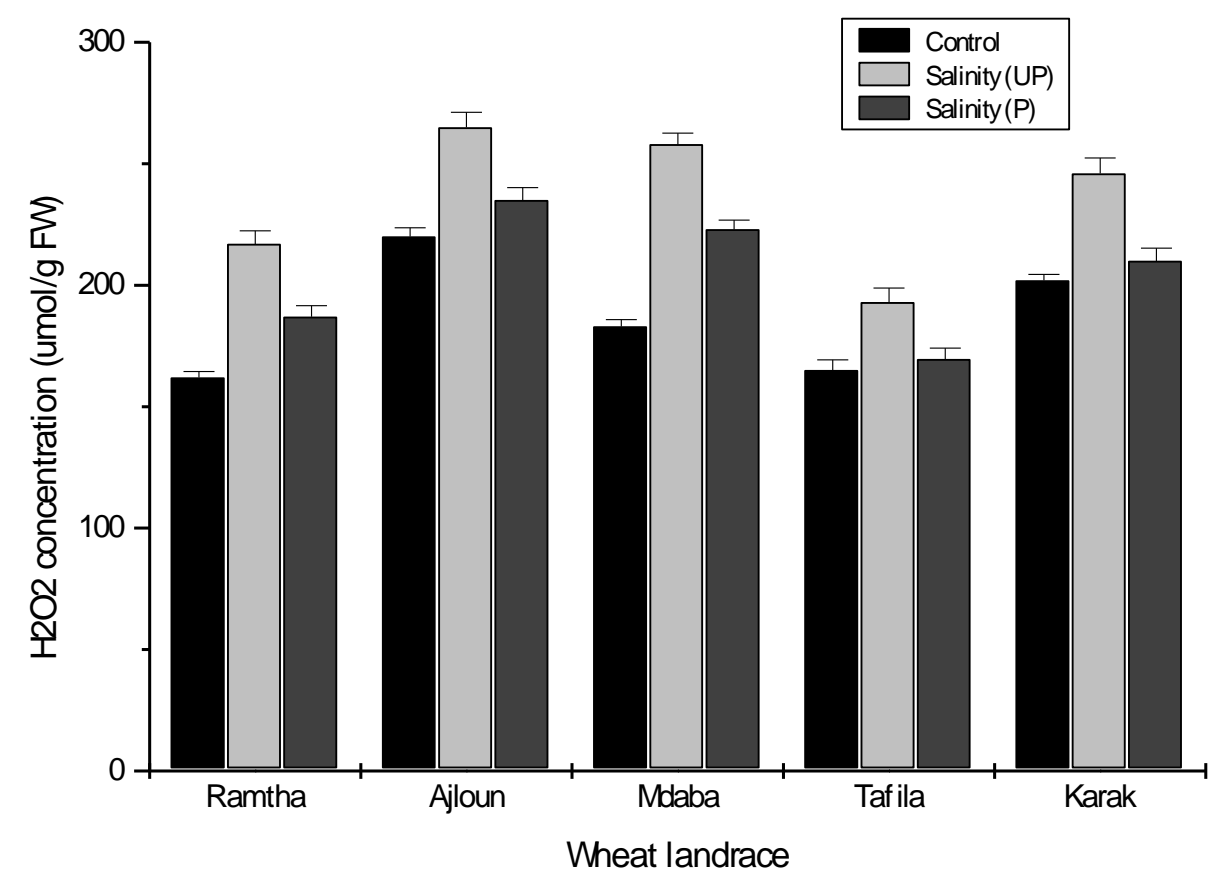

Figure 11. Effect of $\mathrm{CaCl}_{2}$ priming on the content of $\mathrm{H}_{2} \mathrm{O}_{2}$ of wheat landraces exposed to $250 \mathrm{mM}$ $\mathrm{NaCl}$ salinity treatment. Data represent means from 5 replicates \pm SE. 


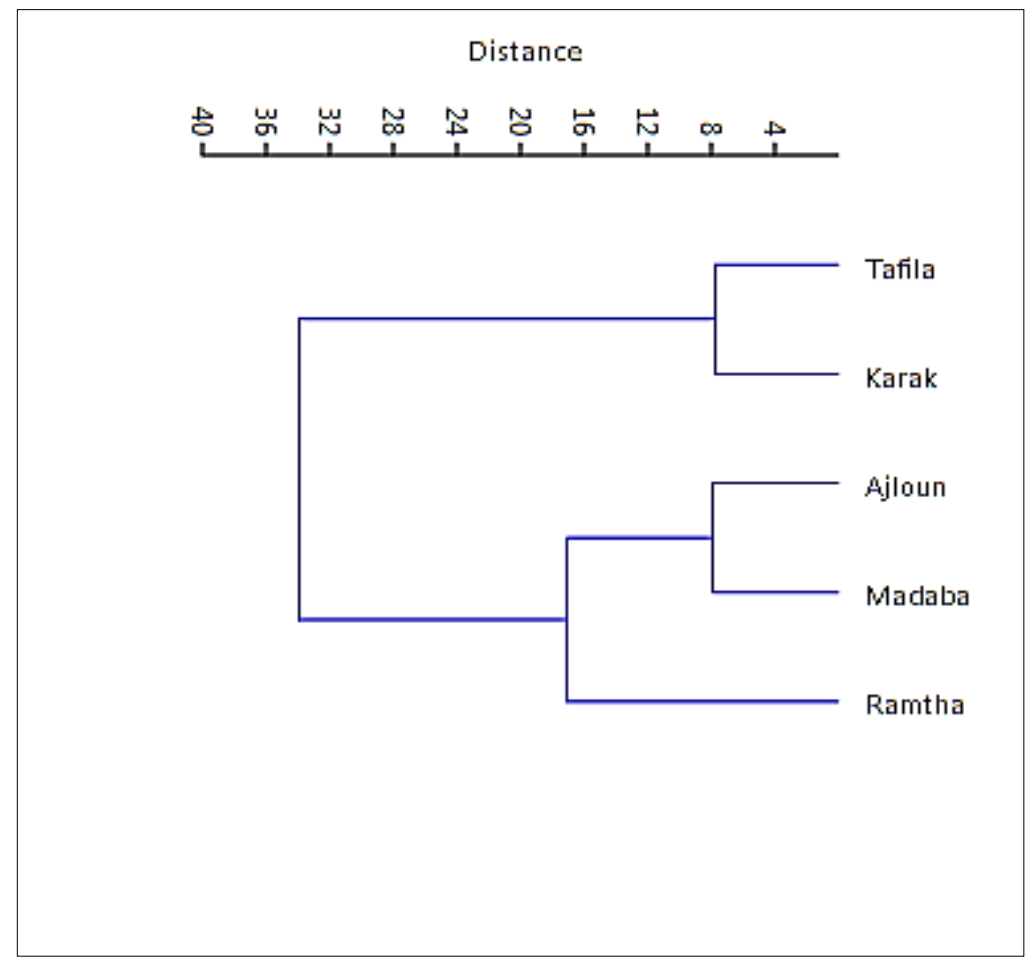

Figure 12. Five Jordanian wheat landraces clustering based on mean tolerance indices of the all parameters tested at $250 \mathrm{mM} \mathrm{NaCl}$ salinity treatment.

\section{Discussion}

Five Jordanian wheat landraces tested showed significant differences for seed germination, seedling growth and biochemical activities under saline conditions. The results also revealed that seed priming improved wheat performance under salinity stress, although maximum improvement was noted in seeds primed with $\mathrm{CaCl}_{2}$.

Seed germination is an important and vulnerable stage in the life cycle of higher plants. Consequently, the determination of germination percentage is one of the most widely used methods in the study of salt tolerance of plants (Dantas et al., 2005). The data of this investigation showed that salinity significantly reduced germination percentage in all wheat landraces under study, although Tafila and Karak landraces were the least affected by the imposed salinity. The inhibition of seed germination by salinity is well documented and has been previously reported for several plants including wheat (Almansouri et al., 2001). Various seed priming treatments were employed to improve seed germination under saline condition (Jisha et al., 2013 ). In this work seed priming with $\mathrm{CaCl}_{2}$ proved to be superior to $\mathrm{NaCl}$ priming or hydropriming treatments in alleviating salinity-induced inhibition of germination. This finding is consistent with previous studies that demonstrated the effectiveness of $\mathrm{CaCl}_{2}$ priming in reducing the inhibitory effects of salinity on seed germination of wheat (Farooq et al., 2008; Afzal et al., 2008; Jafar et al., 2012) maize (Ashraf and Rauf, 2001) and rice (Farooq et al., 2006; Afzal et al., 2012). The positive influence of $\mathrm{CaCl}_{2}$ priming on seed germination may be due to the enhancement effect of calcium on the expression, stability and activity of $\alpha$-amylase, a key germination enzyme, (Afzal et al., 2012). In addition, , $\mathrm{Ca}^{2+}$ is known to have an antagonistic effect on the uptake of $\mathrm{Na}^{+}$in plants subjected to $\mathrm{NaCl}$ stress and, thus, mitigates the toxic effect of $\mathrm{Na}^{+}$on germination (Anil et al., 2005). This is consistent with the significant germination recovery of seeds inhibited from germination by high concentration of $\mathrm{NaCl}$ upon transfer to water.

While the tested wheat landraces showed clear variation in their growth and development in response to saline stress (reflecting differences in physiological and biochemical characteristics that have occurred in the process of salt tolerance), the role of $\mathrm{CaCl}_{2}$ priming in alleviating the adverse effects of salinity on growth of wheat seedlings and identification of physiological and biochemical processes responsible for the improved survival and growth was evaluated. 
Improvement of shoot dry weight under salinity by priming constitutes a direct evidence for the beneficial effect of priming on seedling growth and vigor. Shoot dry weight of the 5 wheat landraces tested was significantly improved by $\mathrm{CaCl}_{2}$ priming. This finding is in agreement with previous researchers who reported the positive effects of priming on shoot dry weight under salinity (Mohamed and Basalah, 2015). This improvement could be due to the positive role of calcium in alleviating the harmful effects of salinity on growth. For instance, it has been shown that $\mathrm{Ca}^{2+}$ signal the cells to enter into early mitotic cycle (Rajendra et al., 2005) thus accounting for more growth and suggesting that the stimulatory effect of $\mathrm{CaCl}_{2}$ on shoot dry weight may be attributed to increased cell division within the apical meristems. Additionally $\mathrm{Ca}^{2+}$ is reported to alleviate the reduction of cell wall extensibility caused by salts (Zidan et al., 1990) and/or water conductance of the plasma membrane (Azaizeh et al., 1992) thus favoring water uptake and growth.It is also possible that reduced membrane leakage and decreased permeability of many ion channels mediated by $\mathrm{Ca}^{+2}$ (Tyerman and Skerrett, 1999) may have reduced the efflux of intracellular solutes and maintained low tissue $\Psi \mathrm{W}$ needed for continued growth under the adverse osmotic effects of salinity. Such possibility is consistent with the results that $\mathrm{CaCl}_{2}$ priming improved tissue RWC and significantly increased membrane stability index. Nonetheless, the significant increase in chlorophyll content by $\mathrm{CaCl}_{2}$ priming is likely to be associated with its positive effect on growth. The increase in chlorophyll content is expected to permit higher rates of photosynthetic activity to meet plant nutritional requirement under salinity (Afzal et al., 2012). Increased chlorophyll content by $\mathrm{CaCl}_{2}$ priming have been previously reported (Farooq et al., 2009; Afzal et al., 2012; Joshi et al., 2013) and is suggested to be the result of both a decrease in the activity of chlorophyllase (Issam et al., 2012) and reduction of reactive oxygen species released during stress (Sevengor et al., 2011). More recently the priming induced proline accumulation is proved to play an important role in protecting chlorophyll from degradation (Hayat et al., 2012; Wani et al., 2016). The results showing that $\mathrm{CaCl}_{2}$ priming reduced $\mathrm{H}_{2} \mathrm{O}_{2}$ content and increased proline accumulation in stressed wheat seedlings extended support to these assumptions. It is now widely accepted that salt stress stimulates the formation of various reactive oxygen species. ROS results in a variety of metabolic disturbances including photosynthetic component and is considered a major cause of membrane and protein damage besides enzyme inactivation (Mittler, 2002). Several studies used the level of $\mathrm{H}_{2} \mathrm{O}_{2}$ in plants as an indicator of oxidative stress (Shulavev and Oliver, 2006). Therefore, the reduction of $\mathrm{H}_{2} \mathrm{O}_{2}$ accumulation by $\mathrm{CaCl}_{2}$ in wheat plants under stress suggested that $\mathrm{CaCl}_{2}$ priming protected wheat from the oxidative damage of ROS. This finding is in agreement with previous reports suggesting that $\mathrm{Ca}^{2+}$ inhibited enhanced production of ROS under salinity (Nemat Alla et al., 2014).

Consistent with its role in enhancing growth and development under salinity, $\mathrm{CaCl}_{2}$ priming treatment induced a significant increase in proline content in stressed wheat plants. Proline is known to occur widely in higher plants and normally accumulates in response to environmental stress (Hayat et al., 2012). It plays an important role in reducing the damaging effects of salinity and accelerates the repairing processes following stresses (Yu Lei and Shaozheng, 2000). The role of proline in osmotic adjustment and in stabilizing the structure of macromolecules and organelles is well established (Sumithra et al., 2006). Therefore, the finding that $\mathrm{CaCl}_{2}$ priming increased the accumulation of proline in wheat under salinity may suggest that the up-regulation of proline level by $\mathrm{CaCl}_{2}$ is an important component of the system by which this priming treatment counteracted the adverse effects of salinity.

Like proline, accumulation of total soluble sugars is a common phenomenon under stress condition (Murakeozy et al., 2003). It has an important role in osmoregulation and maintaining growth (Ashraf and Harris, 2004). This trend is supported by our results which demonstrated the accumulation of soluble sugars in wheat plants in response to saline environment. The increased accumulation of soluble sugars in $\mathrm{CaCl}_{2}$ primed plants under stress agrees with previously reported enhancement of soluble sugar accumulation by $\mathrm{CaCl}_{2}$ priming in stressed wheat and barley (Afzal et al., 2008) and emphasizes the positive role of $\mathrm{CaCl}_{2}$ priming in protecting plants from the damaging effects of salinity.

NR is a primary enzyme in the nitrate assimilation pathway and a limiting factor in plant growth and development. A number of reports demonstrated that NR activity decreases by salt stress (Abd El-Baki et al., 2000). In the present work similar reduction of NR activity was observed in wheat plants 
subjected to salinity. $\mathrm{CaCl}_{2}$ priming, on the other hand, was highly effective in improving the NR activity in stressed plants of all landraces tested. The strong dependence of NR activity on nitrate flux from roots to the site of enzyme activity (Azco'n et al., 1996) suggests that $\mathrm{CaCl}_{2}$ priming may have improved NR activity by upholding water relation (either directly or indirectly) and facilitating the $\mathrm{NO}_{3}$ - flux from roots to leaf which is greatly reduced by salinity.

Findings of this study indicating that $\mathrm{CaCl}_{2}$ priming had no significant influence on the level of soluble proteins in $\mathrm{NaCl}$ stressed wheat plants is contradictory to some reports suggesting that priming increased soluble protein content in stressed plants (Zerrad et al., 2008). This finding, however, is consistent with the recent findings of Yasmeen et al., 2013 who showed that $\mathrm{CaCl}_{2}$ priming had no effect on (or even reduced) soluble protein content in leaves of wheat plants exposed to salinity. It is therefore possible that variation exists among wheat plants with respect to this response.

In addition to demonstrating that $\mathrm{CaCl}_{2}$ priming had a notable beneficial effect on germination and seedling growth under salinity, this study showed broad intra-specific variation in salinity tolerance among the tested wheat landraces. The overall cluster analysis of tolerance indices showed that Tafila and Karak were more tolerant landraces whereas, Ajloun, Madaba and Ramth landraces were less tolerant or more susceptible to salinity. In conclusion the results of the present study showed that seed priming with $50 \mathrm{mM} \mathrm{CaCl} 2$ enhanced the capacity of wheat to withstand salinity. The enhancement of parameters such as total chlorophyll contens, proline accumulation, soluble sugars content and NR activity, in addition to reducing oxidative damage by ROS are among the important manifestations of seed priming with $\mathrm{CaCl}_{2}$. Thus, $\mathrm{CaCl}_{2}$ priming can serve as an effective treatment for the improvement of physiological and metabolic processes that may increase the tolerance of wheat plants to salinity.

\section{Acknowledgement}

The author wishes to thank the University of Jordan for the sabbatical leave offered to him during which this work carried out.

\section{References}

[1]. Abd-El Baki, G. K., Siefritz, F., Man, H. M., Weiner, H., Haldenhoff, R. \& Kaiser, W. M. (2000) Nitrate reductase in Zea mays L. under salinity. Plant, Cell and Environment, 23, 515-521. https://doi.org/10.1046/j.1365-3040.2000.00568.x

[2]. Afzal, I., Basra, S. M. A., Shahid, M., Farooq, M. \& Saleem, M. (2008). Priming enhances germination of spring maize (Zea mays L.) under cool conditions. Seed Science and Technology, 36, 497-503. https://doi.org/10.15258/sst.2008.36.2.26

[3]. Afzal, I., Butt, A., Ur Rehman, H., Basra, S. M. A. \& Afzal A. (2012). Alleviation of salt stress in fine aromatic rice by seed priming. Aust. J. Crop Sci. (10), 1401-1407.

[4]. Almansouri, M., Kinet, J. M. \& Lutts, S. (2001). Effect of salt osmotic stresses on germination in durum wheat (Triticum durum Desf.). Plant and Soil, 231, 243-254. https://doi.org/10.1023/A:1010378409663

[5]. Anil, V. S., Krishnamurthy, P., Kuruvilla, S., Sucharitha, K., Thomas, G. \& Mathew, M. K. (2005). Regulation of the uptake and distribution of $\mathrm{Na}^{+}$in shoots of rice (Oryza sativa) variety Pokkali: role of $\mathrm{Ca}^{2+}$ in salt tolerance response. Physiologia Plantarum, 124, 451-464. https://doi.org/10.1111/j.1399-3054.2005.00529.x

[6]. Apel, K. \& Hirt, H. (2004). Reactive Oxygen species: metabolism, oxidative stress and signal transduction. Annu. Rev. Plant Biol. 55, 373-399.

https://doi.org/10.1146/annurev.arplant.55.031903.141701 PMid:15377225

[7]. Aron, D. (1949). Copper enzymes isolated chloroplasts, polyphenoloxidase in Beta vulgaris. Plant Physiol. 24, 1-15. https://doi.org/10.1104/pp.24.1.1

[8]. Ashraf, M. \& Harris, P. J. C. (2004). Potential biochemical indicators of salinity tolerance in plants. Plant Sci. 166, 3-16. https://doi.org/10.1016/j.plantsci.2003.10.024 
[9]. Ashraf, M. \& Rauf, H. (2001). Inducing salt tolerance in maize (Zea mays L.) through seed priming with chloride salts: Growth and ion transport at early growth stages. Acta. Physio. Planta. 23, 407-414. https://doi.org/10.1007/s11738-001-0050-9

[10]. Ashraf, M., Mukhtar, N., Rehman, S. \& Rha, E. S. (2004). Salt-induced changes in photosynthetic activity and growth in a potential plant Bishop, sweed (Ammolei majus L.). Photosynthetica, 42, 543-50. https://doi.org/10.1007/S11099-005-0011-4

[11]. Azaizeh, H., Gunse, B. \&Steudle, E. (1992). Effects of $\mathrm{NaCl}$ and $\mathrm{CaCl} 2$ on water transport across root cells of maize (Zea mays L.) seedlings. Plant Physiol. 99, 886-894.

https://doi.org/10.1104/pp.99.3.886

PMid:16669016 PMCid:PMC1080560

[12]. Azco'n, R., Go'mez, M. \& Tobar, R. M. (1996). Physiological and nutritional responses by Lactuca sativa L. to nitrogen sources and mycorrhizal fungi under drought conditions. Biology and Fertility of Soils, 22, 156-161. https://doi.org/10.1007/BF00384448

[13]. Basra, S. M. A., Afzal, I., Hameed, A. \& Rashid R. A. (2005). Inducing salt tolerance in wheat by seed vigor enhancement technique. International Journal of Agriculture and Biology, 2(1), 173179.

[14]. Bates, L., Waldren, R. P. \& Teare, I. D. (1973). Rapid determination of free proline for waterstress studies. Plant and Soil, 39, 205-207. https://doi.org/10.1007/BF00018060

[15]. Bewley, J. D. \& Black, M. (1994). Seeds: Physiology of Development and Germination. New York: Plenum Press. https://doi.org/10.1007/978-1-4899-1002-8

[16]. Bradford, M. M. (1976). A rapid and sensitive method for the quantitation of microgram quantities of protein utilizing the principle of protein-dye binding. Analytical Biochemistry, 72, 248-254. https://doi.org/10.1016/0003-2697(76)90527-3

[17]. Brush, S. B. (1999). Genes in the field: On-farm conservation of crop diversity. IPGRI/ IDRC/Lewis Publishers. pp. 51-76. https://doi.org/10.1201/9781420049824

[18]. Dantas, B. F., Ribeiro, L. D. S. \& Aragao, C. A. (2005). Physiological response of cowpea seeds to salinity stress. Rev. Bras. Sementes, 27, 144-148.

https://doi.org/10.1590/S0101-31222005000100018

[19]. Dubey, R. S. (2005). Photosynthesis in plants under stressful conditions. In: M. Pessarakli (Ed.). Photosynthesis handbooks. 2nd Ed. C. R. C. Press, New York. pp. 717-718.

[20]. Farooq, M., Habib, M., Rehman, A., Wahid, A. \& Munir, R. (2011). Employing aqueous allelopathic extracts of sunflower in improving salinity tolerance of rice. Journal of Agriculture and Social Sciences, 7, 75-80.

[21]. Farooq, M., Basra, S.M.A., Wahid, A., Khaliq, A. \& Kobayashi, N. (2009). Rice seed invigoration. In Sustainable Agriculture Reviews. Book Series, ed. E. Lichtfouse. Berlin, Germany: Springer.

[22]. Farooq, M., Basra, S. M. A., Rehman, H. \& Saleem, B. A. (2008). Seed priming enhances the performance of late sown wheat (Triticum aestivum L.) by improving chilling tolerance. J. Agron. Crop Sci., 194, 55-60. https://doi.org/10.1111/j.1439-037X.2007.00287.x

[23]. Farooq, M., Basra ,S.M.A. \& Wahid, A. (2006). Priming of field sown rice seed enhances germination, seedling establishment, allometry and yield. Plant Growth Regul. 49,285-294. https://doi.org/10.1007/s10725-006-9138-y

[24]. Hayat, S., Hayat, Q., Alyemeni, M. N., Wani, A. S., Pichtel, J. \& Ahmad, A. (2012). Role of proline under changing environments. Plant Signal Behav. 7(11), 1456-1466.

https://doi.org/10.4161/psb.21949

PMid:22951402 PMCid:PMC3548871

[25]. ISTA, International Rules for Seed Testing (ISTA) (1985). Seed Sci. Technol. 13,299-335

[26]. Iqbal, N., Ashraf, M. Y., Javed, F., Vicente, M. \& Kafeel, A. (2006). Nitrate reduction and nutrient accumulation in wheat (Triticumaestivum L.) grown in soil salinization with four different salts. J. Pl. Nutr. 29, 409-421. https://doi.org/10.1080/01904160500524852

[27]. Issam, N., Kawther, M., Haythem, M. \& Moez. J. (2012). Effects of $\mathrm{CaCl}_{2}$ pretreatment on antioxidant enzyme and leaf lipid content of faba bean (Vicia faba L.) seedlings under cadmium stress. Plant Growth Regul. 68, 37-47. https://doi.org/10.1007/s10725-012-9691-5

[28]. Jafar, M. Z., Farooq, M., Cheema, M. A., Afzal, I., Basra, S. M. A., Wahid, M. A., Aziz, T. \& Shahid, M. (2012). Improving the performance of wheat by seed priming under saline conditions. $J$. Agron. Crop Sci., 198, 38-45. https://doi.org/10.1111/j.1439-037X.2011.00485.x 
[29]. Jaleel, C. A., Gopi, R., Manivannan, P. \& Panneerselvam, R. (2008). Soil salinity alters the morphology in Catharanthus roseus and its effects on endogenous mineral constituents. Eur. Asia J. Bio. Sci. 2 (2), 18-25.

[30]. Jamal, Y., Shafi, M., Bakht, J. \& Arif, M. (2011). Effect of seed priming on growth and biochemical parameters of wheat under saline conditions. African J. Biotech. 10(75), 17127-17133.

[31]. Jin, P. H., Kim, W. \& Yun, D.(2016). A new insight of salt stress signaling in plant. Mol. Cells, $39(6), 447-459$.

https://doi.org/10.14348/molcells.2016.0083

PMid:27239814 PMCid:PMC4916396

[32]. Jisha, K. C., Vijayakumari, K. \& Puthur, J. T. (2013). Seed priming for abiotic stress tolerance: an overview. Acta Physiol. Plant. 35, 1381-1396.

https://doi.org/10.1007/s11738-012-1186-5

[33]. Joshi, R., Rao, M. V \& Baisakh, N. (2013) Arabidopsis plants constitutively overexpressing a myo-inositol 1-phosphate synthase gene (SaINO1) from the halophyte smooth cordgrass exhibits enhanced level of tolerance to salt stress. Plant Physiol. Bioche. 65, 61-66.

https://doi.org/10.1016/j.plaphy.2013.01.009

PMid:23416497

[34]. Kochak-Zadeh, A., Mousavi, S. \& Nejad, M. (2013). The effect of salinity stress on germination and seedling growth of native and breeded varieties of wheat. J. Nov. Appl. Sci. 2(12), 703709.

[35]. Lorenzo, H., Siverio, J. \& Caballero, M. (2001). Salinity and nitrogen fertilization and nitrogen metabolism in rose plants. J. Agric. Sci. 137, 77-84.

https://doi.org/10.1017/S0021859601001150

[36]. Mittler, R. (2002). Oxidative stress, antioxidants and stress tolerance. Trends Plant Sci. 7, 405410. https://doi.org/10.1016/S1360-1385(02)02312-9

[37]. Mohamed, A. \& Basalah, M. O. ( 2015). The Active Role of Calcium Chloride on Growth and Photosynthetic Pigments of Cowpea "Vigna unguiculata L. (Walp)" Under Salinity Stress Conditions. Am-Euras. J. Agric. \& Environ. Sci. 15(10), 2011-2020.

[38]. Mozafari, H., Kalantari, K. M., Olia'ie, M. S., Torkzadeh, M., Salari, H. \& Mirzaei, S. (2008). Role of Calcium in Increasing Tolerance of Descurainia sophia to Salt Stress . J. Agri. Soc. Sci. 4(2) , 5358.

[39]. Munns, R., James, R. A. \& Lauchli, A. (2006). Approaches to increasing the salt tolerance of wheat and other cereals. J. Exp. Bot. 57, 1025-1043.

https://doi.org/10.1093/jxb/erj100

PMid:16510517

[40]. Murakeozy, E. P., Nagy ,Z., Duhaze, C., Bouchereau ,A. \& Tuba, Z. (2003). Seasonal changes in the levels of compatible osmolytes in three halophytic species of inland saline vegetation in Hungary. J. Plant Physiol. 160, 395-401.

https://doi.org/10.1078/0176-1617-00790

PMid:12756919

[41]. Muranaka, S., Shimizu, K. \& Kato, M. (2002). A salt-tolerant cultivar of wheat maintains photosynthetic activity by suppressing sodium uptake. Photosynthetica, 40, 509-515.

[42]. Nemat Alla, M. M. \& Abogadallah, G. M. (2014). Supplementary CaCl2 ameliorates wheat tolerance to NaCl. Acta Pysiol. Plant. 36, 2103-2112.

https://doi.org/10.1007/s11738-014-1587-8

[43]. Park, H. J., Kim, W. \& Yun, D. (2016). A New Insight of Salt Stress Signaling in Plant. Mol. Cells., $39(6), 447-459$.

https://doi.org/10.14348/molcells.2016.0083

PMid:27239814 PMCid:PMC4916396

[44]. Rajendra, P., Sujatha, N. H., Sashidkar, R. B., Subramanyam, C., Davendranath, D., Gunasekaran, B., Aradhya, R. S. S. \& Bhaskaran, A. (2005). Effects of power frequency electromagnetic fields on growth of germinating Vicia faba L., the broad bean. Electromagnetic Biology and Biology and Medicine, 24, 39-54. https://doi.org/10.1081/JBC-200055058

[45]. Rosielle, A. A. \& Hamblin, J. (1981). Theoretical aspects of selection for yield in stress and nonstress environments. Crop Sci. J. 21, 943-946.

https://doi.org/10.2135/cropsci1981.0011183X002100060033x 
[46]. Sairam, R. K. (1994). Effect of moisture stress on physiological activities of two contrasting wheat genotypes. Indian. J. Exp. Biol. 32, 594-597.

[47]. Sevengor, S., Yasar, F., Kusvura, S. \& Ellialtýoglu, S. (2011). The effect of salt stress on growth, chlorophyll content, lipid peroxidation and antioxidative enzymes of pumpkin seedling. Afr. J. Agr. Res. 6(21), 4920-4924

[48]. Shulavev, V. \& Oliver, D. J. (2006). Metabolic and proteomic markers for oxidative stress. New tools for reactive oxygen species research. Plant Physiol. 141, 367-372.

https://doi.org/10.1104/pp.106.077925

PMid:16760489 PMCid:PMC1475455

[49]. Silveira, J. A. G., Matos, J. C. S., Ceccato, V. M., Sampaio, A. H., Costa, R. C. L. \& Viégas R. A. (1998). Induction of nitrate reductase activity and nitrogen fixation in two Phaseolus species in relation to exogenous nitrate level. Physiol. Mol. Biol. Plants, 4, 181-188

[50]. Steel, R.G.D., Torrie, J.H. \& Dickey, D.A. (1997). Principles and procedures of statistics, a biometrical approach. 3rd edition. McGraw-Hill Co. Inc., New York.

[51]. Sumithra, K., Jutur, P. P., Carmel, B. D. \& Reddy, A. R. (2006). Salinity-induced changes in two cultivars of Vigna radiate: responses of antioxidative and proline metabolism. Plant Growth Regul. 50, 11-22. https://doi.org/10.1007/s10725-006-9121-7

[52]. Tyerman, S. D. \& Skerrett, I. M. (1999). Root ion channels and salinity. Sci. Hort. 78, 175-235. https://doi.org/10.1016/S0304-4238(98)00194-0

[53]. Van Hoorn, J. W. (1991). Development of soil salinity during germination and early seedling growth and its effect on several crops. Agric. Water Manage. 20, 17-28. https://doi.org/10.1016/0378-3774(91)90032-E

[54]. Velikova, V., Yordanov, I. \& Edreva, A. (2000). Oxidative Stress and Some Antioxidant Systems in Acid RainTreated Bean Plants: Protective Role of Exogenous Polyamines. Plant Science, 151, 59-66. https://doi.org/10.1016/S0168-9452(99)00197-1

[55]. Wahid, A., Perveen, M., Gelani, S. \& Basra, S. M. A. (2007). Pretreatment of seed with $\mathrm{H}_{2} \mathrm{O}_{2}$ improves salt tolerance of wheat seedlings by alleviation of oxidative damage and expression of stress proteins. J. Pl. Physiol. 164(3), 283-294. https://doi.org/10.1016/j.jplph.2006.01.005, PMid:16545492

[56]. Wani, A. S, Ahmad, A., Hayat, S. \& Tahir, I. (2016). Is foliar spray of proline sufficient for mitigation of salt stress in Brassica juncea cultivars? Environ. Sci. Pollut. Res. 23, 13413. https://doi.org/10.1007/s11356-016-6533-4, PMid:27026543

[57]. Wyn Jones, R. G. (1981). Salt tolerance. In: C. B. Johnson (ed.). Physiological processes limiting plant productivity. Butterworths, London. pp. 271-292. https://doi.org/10.1016/B978-0-408-10649-8.50019-8

[58]. Yancey, P. H. (2005). Organic osmolytesas compatible metabolic and counteracting cytoprotectants in high osmolarity and other stress. J. Exp. Biol. 208, 2819-2830.

https://doi.org/10.1242/jeb.01730

PMid:16043587

[59]. Yasmeen, A., Basra, S.M.A., Wahid, A., Farooq ,M., Nouman, W., Rehman H.U. \& Hussain N. (2013). Improving Drought Resistance in Wheat (Triticum aestivum) by Exogenous Application of Growth Enhancers. Int. J. Agric. Biol., 15, 1307-1312

[60]. Yemm, E. W. \& Willis, A. J. (1954). The Estimation of Carbohydrate in the Plant Extract by Anthrone Reagent. Journal of Biochemistry, 57, 508-514. https://doi.org/10.1042/bj0570508

[61]. Yu Lei, M. K. \& Shaozheng, L. (2000). Research on salt tolerance of some tree species on muddy seashore of north China. In: International seminar on "Prospects for saline agriculture". April 10-12, Islamabad (Pakistan).

[62]. Zerrad, W., Maataoui, B.S., Hilali, S., El Antri, S. \& Hmyene, A. (2008). Etude comparative des mecanismes biochimiques de resistance au stress hydrique de deux variétés de blé dur. Lebanese Science Journal, 9(2), 27-36

[63]. Zidan, I., Azaizeh, H. \& Neumann, P. M. (1990). Does salinity reduce growth in maize root epidermal cells by inhibiting their capacity for cell wall acidification? Plant Physiol. 93, 7-11. https://doi.org/10.1104/pp.93.1.7, PMid:16667468 PMCid:PMC1062459 